\title{
Polymorphism of IFN- $\gamma+874$ T/A associated with production of IFN- $\gamma$ affects human papillomavirus susceptibility in rural women from Luohe, Henan, China
}

This article was published in the following Dove Press journal: OncoTargets and Therapy

\author{
Qing-wei Zhang' \\ Jia-yu Song ${ }^{2}$ \\ Jiang-hua $\mathrm{Yu}^{\prime}$ \\ Ming-zhen Sun ${ }^{2}$ \\ Si-yuan Tang' \\ Shao-zhe Yang' \\ Lei-jia Cao' \\ Hui-fen Wang' \\ Li-na Cui' \\ Xiu-hong $\mathrm{Fu}^{\prime}$
}

'Department of Obstetrics and Gynaecology, Luohe Central Hospital, Luohe, 462000, Henan, China;

${ }^{2}$ Department of Pharmacology, Luohe Medical College, Luohe, 462000 ,

Henan, China
Correspondence: Jia-yu Song Department of Pharmacology, Luohe Medical College, No I48, University Road, Yuanhui, Luohe, 462000,

Henan, China

Tel/fax +86 3952969417

Email songjiayu1986@2Icn.com
Purpose: In this paper, the association between polymorphisms of IFN- $\gamma+874 \mathrm{~T} / \mathrm{A}$ (rs2430561), IFN- $\gamma \mathrm{R} 1-56 \mathrm{~T} / \mathrm{C}(\mathrm{rs} 2234711)$, IFN- $\gamma \mathrm{R} 1+95 \mathrm{C} / \mathrm{T}$ (rs7749390), and IFN- $\gamma \mathrm{R} 1-611 \mathrm{~A} / \mathrm{G}$ (rs 1327474) and human papillomavirus (HPV) susceptibility was investigated in rural women from Luohe, Henan, China.

Patients and methods: A total of 520 rural women were enrolled from Luohe, including 260 with HPV infection and mild dysplasia or less and 260 without HPV infection. Singlenucleotide polymorphisms (SNPs) of IFN- $\gamma+874 \mathrm{~T} / \mathrm{A}$, IFN- $\gamma \mathrm{R} 1-56 \mathrm{~T} / \mathrm{C}$, IFN- $\gamma \mathrm{R} 1+95 \mathrm{C} / \mathrm{T}$ and IFN- $\gamma \mathrm{R} 1-611 \mathrm{~A} / \mathrm{G}$ were genotyped using TaqMan Pre-Designed SNP Genotyping Assays. Serum IFN- $\gamma$ levels were measured using Human IFN- $\gamma$ Quantikine ELISA Kit. Multivariate logistic regression analysis was performed to identify the SNPs associated with HPV susceptibility. Serum IFN- $\gamma$ levels were compared between different genotypes.

Results: The polymorphism of IFN- $\gamma+874 \mathrm{~T} / \mathrm{A}$ was associated with HPV susceptibility and $+874 \mathrm{~A}$ carriers had an increased risk. Moreover, the odds ratio was higher in $+874 \mathrm{AA}$ carriers than in +874 AT carriers (1.672 vs 2.874 ). Serum IFN- $\gamma$ levels were highest in IFN- $\gamma+874$ TT carriers, intermediate in AT carriers, and lowest in AA carriers $(2.86 \pm 1.14$ vs $1.57 \pm 0.79$ vs $0.41 \pm 0.22 \mathrm{pg} / \mathrm{mL}$, all $P<0.05)$.

Conclusion: The polymorphism of IFN $-\gamma+874 \mathrm{~T} / \mathrm{A}$ was associated with HPV susceptibility in rural women from Luohe, Henan, China, and $+874 \mathrm{~A}$ carriers had an increased risk. The possible mechanism was that $+874 \mathrm{~A}$ carriers had a low production of IFN- $\gamma$.

Keywords: single-nucleotide polymorphisms, IFN- $\gamma$, IFN- $\gamma \mathrm{R} 1$, human papillomavirus, susceptibility

\section{Introduction}

As one of the most common cancers in women around the world, ${ }^{1,2}$ cervical cancer led to $>266,000$ deaths in 2012 alone. ${ }^{3}$ In China, cervical cancer is the second most common gynecologic cancer among women, with an increasing incidence and mortality. ${ }^{4,5}$

Human papillomavirus (HPV) is a typical risk factor for cervical cancer as the only confirmed cancer-inducing virus so far. ${ }^{6}$ Cervical HPV infection is common, ${ }^{7,8}$ with a lifetime risk of $80 \%-90 \%{ }^{9}$ Although most HPV infections are transitory, ${ }^{10} 5 \%-10 \%$ of women with persistent infections remain at an increased risk for the development of cervical intraepithelial neoplasia (CIN) 3 and, less commonly, cervical cancer. ${ }^{11}$

The immune system of hosts has an important role in controlling HPV infection. Immunosuppressed women have an increased incidence of HPV infection. ${ }^{12,13}$ The imbalance 
of local inflammatory cytokines, including interferon-gamma (IFN- $\gamma$ ), interleukin (IL)-12 and tumor necrosis factor-alpha, is associated with persistent HPV infection. ${ }^{14-16}$ INF- $\gamma$ has a role in both innate and adaptive immunity, ${ }^{17}$ and can induce cellular resistance to HPV infection. ${ }^{18}$ Both IFN- $\gamma$ and its receptor (IFN- $\gamma \mathrm{R} 1)$ genes are key immune response genes. ${ }^{19}$ The IFN- $\gamma$ gene is located on chromosome $12 \mathrm{q} 24.1$ and encodes IFN $-\gamma{ }^{20}$ The polymorphism of IFN- $\gamma+874 \mathrm{~T} / \mathrm{A}$ (rs2430561) may affect the production of IFN- $\gamma \cdot{ }^{21}$ The IFN- $\gamma \mathrm{R} 1$ gene locates on chromosome 13q31.3-32.1 and encodes the ligand-binding chain of the IFN- $\gamma$ receptor. ${ }^{22}$

In this paper, the association between the polymorphisms of IFN- $\gamma+874 \mathrm{~T} / \mathrm{A}$ (rs2430561), IFN- $\gamma \mathrm{R} 1-56$ $\mathrm{T} / \mathrm{C}(\mathrm{rs} 2234711)$, IFN- $\gamma \mathrm{R} 1+95 \mathrm{C} / \mathrm{T}$ (rs7749390) and IFN- $\gamma$ R1 -611A/G (rs 1327474) and HPV susceptibility was investigated in rural women from Luohe, Henan, China. The aim was to identify susceptible genotypes to HPV infection and, thus, provide useful information for vaccination.

\section{Patients and methods}

\section{Sampling and randomization strategy}

This case-control study employed a multistage randomized sampling strategy. One district was selected from five districts in Luohe using computer-generated random selection, and five villages were selected from this selected district. All women meeting the inclusion criteria in these selected villages were detected for HPV infection. The inclusion criteria included: 1) voluntary participation, 2) age ranging from 22 to 70 years and 3 ) a sexual history of $>3$ years. The exclusion criteria included having a medical history of CIN, or cervical cancer, or hysterectomy.

\section{Participants}

A total of 260 women were randomly selected and allocated to the case group from the screened women with HPV infection and mild dysplasia or less. The case group was matched by the control group $(n=260)$ according to age and village at a ratio of $1: 1$. This study was permitted by the ethics committee of Luohe Central Hospital (201402016), and all participants provided written informed consent.

\section{HPV infection testing}

Cervical tissue cells were collected $>3$ days after menstruation and 72 hours after sexual life or vaginal medication from all participants. The sampling brush was rotated softly in the cervical canals to take specimens, and specimens were then stored in a refrigerator at a temperature of $4^{\circ} \mathrm{C}$. The HPV infection status in the cervical tissue was tested with
Hybrid Capture 2 (HC-2) detector developed by QIAGEN (Hilden, Germany).

\section{Single-nucleotide polymorphism genotyping}

DNA for single-nucleotide polymorphism (SNP) genotyping was extracted from the peripheral blood of participants using salting out method according to Hashemi et al. ${ }^{23} \mathrm{SNPs}$ of IFN- $\gamma+874 \mathrm{~T} / \mathrm{A}$, IFN- $\gamma \mathrm{R} 1-56 \mathrm{~T} / \mathrm{C}$, IFN- $\gamma \mathrm{R} 1+95 \mathrm{C} / \mathrm{T}$ and IFN- $\gamma \mathrm{R} 1-611 \mathrm{~A} / \mathrm{G}$ were genotyped with TaqMan PreDesigned SNP Genotyping Assays (Applied Biosystems, Carlsbad, CA, USA). Polymerase chain reaction amplification and allelic discrimination were performed according to product specifications using the ABI 7500 Fast real-time polymerase chain reaction system (Applied Biosystems).

\section{Measurement of serum IFN- $\gamma$ levels}

Serum IFN- $\gamma$ levels were measured with Human IFN- $\gamma$ Quantikine ELISA Kit (R\&D Systems Europe, Ltd., Abingdon, UK) in all participants, according to the instructions of the manufacturer.

\section{Statistical analysis}

For all SNPs, Hardy-Weinberg equilibrium test, allele frequencies and genotype frequencies were computed with the SNPstats software (a web tool for the analysis of association studies: net/SNPstats). ${ }^{24}$ All factors, including general data and all SNPs, were compared with a chi-squared test between the case group and the control group. The factors with a $P$-value $<0.10$ in univariate analysis were included in the multivariate analysis with a backward stepwise logistic regression model. Multivariate logistic regression analysis was then performed to identify the SNPs associated with HPV susceptibility. Serum IFN- $\gamma$ levels were compared with analysis of variance between different genotypes. The SPSS version 22.0 for Windows (IBM Corporation, Armonk, NY, USA) was employed to perform all statistical analyses. Significance was set at $P<0.05$.

\section{Results}

\section{General data}

The average age of all participants was $41.58 \pm 9.46$ years. According to the results of univariate analysis, annual family income, education level and occupation were statistically different between the case group and the control group, and race, and marital, drinking and smoking status were not statistically different (Table 1). 
Table I General data of the case group and the control group

\begin{tabular}{|c|c|c|c|c|}
\hline Variables & Case group $(n=260)$ & Control group $(n=260)$ & $\chi^{2}$ & $P$-value \\
\hline \multicolumn{5}{|l|}{ Race } \\
\hline Han & $25 \mathrm{I}(96.54 \%)$ & $250(96.15 \%)$ & 0.055 & $>0.05$ \\
\hline Hui/Mongol/Manchu & $9(3.46 \%)$ & $10(3.85 \%)$ & & \\
\hline \multicolumn{5}{|l|}{ Educational level } \\
\hline Primary school and below & $79(30.38 \%)$ & $56(21.54 \%)$ & 28.626 & $<0.001$ \\
\hline Junior high school & I 44 (55.38\%) & II 5 (44.23\%) & & \\
\hline Senior high school and above & 37 (I4.24\%) & 89 (34.23\%) & & \\
\hline \multicolumn{5}{|l|}{ Occupation } \\
\hline Farmer & $218(83.85 \%)$ & I 77 (68.08\%) & $18.00 \mid$ & $<0.001$ \\
\hline Worker & 29 (11.15\%) & $53(20.38 \%)$ & & \\
\hline Civil servant/teacher/doctor & $13(5.00 \%)$ & $30($ (II.54\%) & & \\
\hline \multicolumn{5}{|l|}{ Annual family income (RMB) } \\
\hline$<10,000$ & 199 (76.54\%) & I 48 (56.92\%) & 26.01 & $<0.001$ \\
\hline $10,000-20,000$ & $42(16.15 \%)$ & $60(23.08 \%)$ & & \\
\hline$>20,000$ & $19(7.31 \%)$ & $52(20.00 \%)$ & & \\
\hline \multicolumn{5}{|l|}{ Marital status } \\
\hline Married & 245 (94.23\%) & $249(95.77 \%)$ & 0.648 & $>0.05$ \\
\hline Unmarried/divorced & 15 (5.77\%) & II (4.23\%) & & \\
\hline \multicolumn{5}{|l|}{ Drinking status } \\
\hline Yes & $234(90.00 \%)$ & 239 (91.92\%) & 0.585 & $>0.05$ \\
\hline No & $26(10.00 \%)$ & $21(8.08 \%)$ & & \\
\hline \multicolumn{5}{|l|}{ Smoking status } \\
\hline Yes & $228(87.69 \%)$ & 238 (91.54\%) & 2.066 & $>0.05$ \\
\hline No & 32 (12.31\%) & $22(8.46 \%)$ & & \\
\hline
\end{tabular}

Note: Case group, women with HPV infection and mild dysplasia or less; control group, women without HPV infection.

Abbreviations: HPV, human papillomavirus; RMB, Renminbi.

\section{SNP analysis}

The success rates of genotyping of all SNPs were 100\% in both the control group and the case group. The genotype frequencies of all SNPs did not deviate significantly from those expected under Hardy-Weinberg equilibrium (Table 2). According to the results of univariate analysis, the genotype frequencies of IFN- $\gamma+874 \mathrm{~T} / \mathrm{A}$ and IFN- $\gamma \mathrm{R} 1-56 \mathrm{~T} / \mathrm{C}$ were statistically different between the case group and the control group $(P<0.05)$, and those of IFN- $\gamma \mathrm{R} 1+95 \mathrm{C} / \mathrm{T}$ and IFN- $\gamma \mathrm{R} 1-611 \mathrm{~A} / \mathrm{G}$ were not statistically different $(P>0.05)$.

\section{Multivariate analysis}

Multivariate logistic regression analysis was performed to determine the association between different genotypes of

Table 2 Allele and genotype frequencies of the case group and the control group

\begin{tabular}{|c|c|c|c|c|c|c|}
\hline \multirow{2}{*}{$\begin{array}{l}\text { Single-nucleotide } \\
\text { polymorphisms } \\
\text { IFN- } \gamma+874 \text { T/A }\end{array}$} & \multicolumn{2}{|c|}{ Allele frequency } & \multicolumn{3}{|c|}{ Genotype frequency } & \multirow[t]{2}{*}{ HWE P-value } \\
\hline & $\mathrm{T}$ & A & TT & AT & AA & \\
\hline Case group* & 224 & 296 & 72 & 80 & 108 & $>0.05$ \\
\hline Control group & 302 & 218 & 119 & 79 & 62 & $>0.05$ \\
\hline IFN- $\gamma \mathrm{RI}-56 \mathrm{~T} / \mathrm{C}$ & $\mathrm{T}$ & C & $\mathrm{TT}$ & $\mathrm{CT}$ & $\mathrm{CC}$ & \\
\hline Case group* & 251 & 269 & 64 & 123 & 73 & $>0.05$ \\
\hline Control group & 225 & 295 & 41 & 143 & 76 & $>0.05$ \\
\hline$|F N-\gamma R|+95 \mathrm{C} / \mathrm{T}$ & C & $\mathrm{T}$ & $\mathrm{CC}$ & $\mathrm{CT}$ & TT & \\
\hline Case group & 252 & 268 & 67 & 118 & 75 & $>0.05$ \\
\hline Control group & 249 & 271 & 62 & 125 & 73 & $>0.05$ \\
\hline $\mid F N-\gamma R I-6 I I A / G$ & A & G & AA & AG & GG & \\
\hline Case group & 467 & 53 & 218 & 31 & 11 & $>0.05$ \\
\hline Control group & 458 & 62 & 213 & 32 & 15 & $>0.05$ \\
\hline
\end{tabular}

Note: $* P<0.05$, vs genotype frequency of the control group.

Abbreviations: HWE, Hardy-Weinberg equilibrium; IFN, interferon. 
Table 3 Association between polymorphism of IFN- $\gamma+874$ T/A, IFN- $\gamma R$ I -56 T/C, IFN- $-\gamma R$ I $+95 \mathrm{C} / \mathrm{T}$, IFN- $\gamma \mathrm{RI}-6 \mathrm{IIA} / \mathrm{G}$ and HPV susceptibility

\begin{tabular}{|c|c|c|c|c|c|c|}
\hline Genotypes & $\begin{array}{l}\text { Regression } \\
\text { coefficient }\end{array}$ & $\begin{array}{l}\text { Standard } \\
\text { error }\end{array}$ & Wald & OR & $95 \% \mathrm{Cl}$ & $P$-value \\
\hline IFN- $\gamma+874$ & & & 10.668 & & & 0.003 \\
\hline TT & & & & - & - & Ref $=I$ \\
\hline AT & 0.316 & 0.167 & 8.639 & 1.672 & $1.0912-2.563$ & 0.014 \\
\hline $\mathrm{AA}$ & 0.425 & 0.226 & 12.639 & 2.874 & $|.872-4.4| 4$ & $<0.001$ \\
\hline $\mid \mathrm{FN}-\gamma \mathrm{RI}-56$ & & & 1.217 & & & 0.203 \\
\hline TT & & & & - & - & $\operatorname{Ref}=I$ \\
\hline $\mathrm{CT}$ & 0.249 & 0.136 & 1.329 & 0.551 & $0.232-1.157$ & 0.187 \\
\hline CC & 0.273 & 0.148 & 1.208 & 0.615 & $0.396-1.398$ & 0.209 \\
\hline$|F N-\gamma R|+95$ & & & 1.054 & & & 0.264 \\
\hline $\mathrm{CC}$ & & & & - & - & Ref $=I$ \\
\hline $\mathrm{CT}$ & 0.357 & 0.192 & $\mathrm{I} .145$ & 0.874 & $0.491-1.586$ & $0.24 I$ \\
\hline $\mathrm{TT}$ & 0.282 & 0.159 & 0.967 & 0.951 & $0.619-1.835$ & 0.318 \\
\hline $\mid F N-\gamma R I-6 I I$ & & & 0.987 & & & 0.296 \\
\hline $\mathrm{AA}$ & & & & - & - & $\operatorname{Ref}=I$ \\
\hline$A G$ & 0.174 & 0.126 & 0.871 & 0.946 & $0.608-1.826$ & 0.349 \\
\hline GG & 0.225 & 0.137 & 1.238 & 0.717 & $0.401-1.479$ & 0.195 \\
\hline
\end{tabular}

Abbreviations: HPV, human papillomavirus; IFN, interferon; OR, odds ratio; Ref, reference.

IFN- $\gamma+874 \mathrm{~T} / \mathrm{A}$ and IFN- $\gamma \mathrm{R} 1-56 \mathrm{~T} / \mathrm{C}$ and HPV susceptibility, adjusting for age, annual family income, education level, occupation and smoking status (Table 3). According to the results of multivariate analysis, the polymorphism of IFN- $\gamma+874 \mathrm{~T} / \mathrm{A}$ was associated with HPV susceptibility, and $+874 \mathrm{~A}$ carriers had an increased risk of HPV infection. Moreover, the odds ratio (OR) was higher in +874 AA carriers than in +874 AT carriers (Figure 1).

\section{Serum IFN- $\gamma$ levels}

The results of analysis of variance showed that serum IFN- $\gamma$ levels were highest in IFN- $\gamma+874$ TT carriers, intermediate in AT carriers and lowest in AA carriers (Table 4).

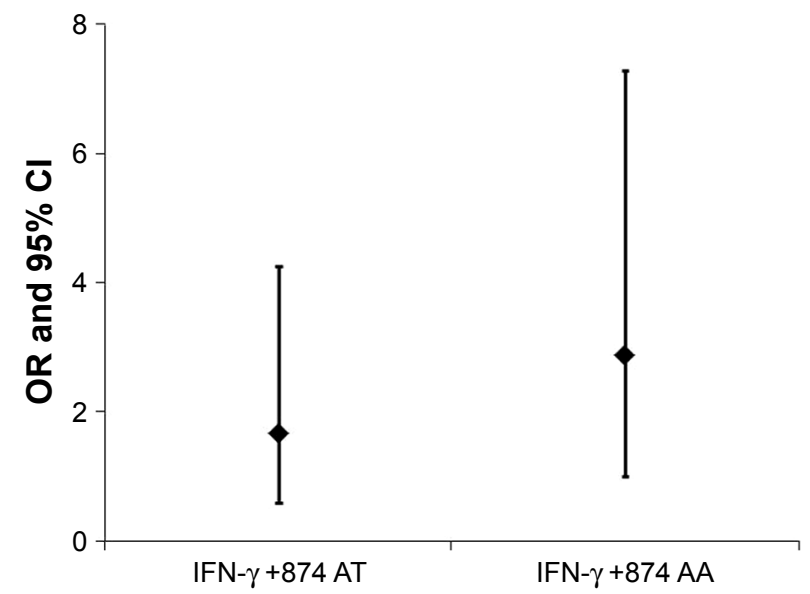

Figure I Association between IFN- $\gamma+874$ T/A polymorphism and human papillomavirus susceptibility.

Note: IFN- $\gamma+874$ TT was used as Ref.

Abbreviations: IFN, interferon; OR, odds ratio; Ref, reference.

\section{Discussion}

Cytokines have a pivotal role in establishing and maintaining immune responses against virus infection. ${ }^{25}$ Polymorphisms of regulating regions of cytokine genes, including $I F N-\gamma$, $I L-6, I L-10$, transforming growth factor beta 1 (TGF- $\beta 1)$ and TNF genes, have been associated with their production, which lead to difference in susceptibility to virus infection. ${ }^{26-30} \mathrm{HPV}$ infection is very common among women. However, the virus is eliminated in most infected women (70\%-90\%) 12-24 months after the initial diagnosis without any intervention. ${ }^{31,32}$

The exact mechanism associated with the clearance of HPV infection remains uncertain. Both the innate and adaptive immune responses are involved in the clearance, persistence or progression of HPV infection. ${ }^{33}$ The innate immune response is thought to be critical in early control of HPV infection as the first line of defense against invading pathogens. ${ }^{34}$ It can coordinate the host responses to prevent

Table 4 Serum IFN- $\gamma$ levels in different genotypes of IFN- $\gamma$ +874 T/A

\begin{tabular}{lll}
\hline Genotypes & $\begin{array}{l}\text { Different } \\
\text { genotypes }(\mathbf{n})\end{array}$ & $\begin{array}{l}\text { Serum IFN- } \boldsymbol{l} \\
\text { levels }(\mathbf{p g} / \mathbf{m L})\end{array}$ \\
\hline IFN- $\gamma+874$ TT & 72 & $2.86 \pm I .14$ \\
IFN- $\gamma+874$ AT & 80 & $1.57 \pm 0.79 *$ \\
IFN- $\gamma+874$ AA & 108 & $0.41 \pm 0.22^{*, \ddagger}$ \\
$F$ & & 8.947 \\
P-value & & $<0.001$ \\
\hline
\end{tabular}

Notes: $* P<0.05$, vs IFN- $\gamma+874$ TT. $\ddagger P<0.05$, vs IFN- $\gamma+874$ AT. Abbreviation: IFN, interferon. 
or reduce viral replication and spread, until the adaptive immune system is established. ${ }^{35}$ Most cervical HPV infections are eliminated or suppressed through cell-mediated immunity with CD4+ and CD8+ T cells as the major effector cells, ${ }^{36}$ and the Th1 response is associated with clearance of the HPV infection. ${ }^{37}$

As a T-helper 1 proinflammatory cytokine, IFN- $\gamma$ is produced during virus infection. IFN- $\gamma$ has a pivotal role in defense against HPV through inducing cell-mediated inflammatory responses. ${ }^{38,39}$ Telesheva et al found that the outcome of HPV infection is correlated with the interferon component of the immune response. ${ }^{40}$ A persistent HPV infection is characterized by decreased levels of IFN- $\alpha$, and transient infection is associated with increased levels of IFN- $\gamma$ and IFN- $\alpha$. Song et al investigated 57 women with high-risk HPV (HR-HPV) infection and untreated mild dysplasia or less. After a follow-up period of 12 months, HPV was not detectable in $93.3 \%$ (28/30) of women who were IFN- $\gamma$ positive and in $66.7 \%(18 / 27)$ of women who were IFN- $\gamma$ negative. Multivariate analysis showed that IFN- $\gamma$ positive status was significantly associated with clearance of HR-HPV (OR: 8.26; 95\% CI: 1.24-54.94). Therefore, they concluded that IFN- $\gamma$ may be a prognostic marker for clearance of HR-HPV. ${ }^{15}$

As the encoding gene of IFN- $\gamma, I F N-\gamma$ gene may affect the production of IFN- $\gamma$ through an SNP located in the first intron at the $5^{\prime}$ end adjacent to a CA repeat region (+874T/A polymorphism). ${ }^{21}$ IFN- $\gamma+874$ TT genotype produces a high level of IFN- $\gamma$ and helps the host's defense against viral infection. Conversely, the genotypes AA and AT cause low IFN- $\gamma$ production, which may increase the risk of viral infection. ${ }^{41-45}$

According to our results, the polymorphism of IFN- $\gamma+874$ T/A was associated with HPV susceptibility, and $+874 \mathrm{~A}$ carriers had an increased risk of HPV infection. Moreover, the OR was higher in +874 AA carriers than in +874 AT carriers. The serum levels of IFN- $\gamma$ were +874 TT carriers $>$ AT carriers $>$ AA carriers. Therefore, the polymorphism of IFN- $\gamma+874$ T/A affected HPV susceptibility through modulating the production of IFN- $\gamma$. Meanwhile, the polymorphisms of IFN- $\gamma \mathrm{R} 1-56 \mathrm{~T} / \mathrm{C}, \mathrm{IFN}-\gamma \mathrm{R} 1+95 \mathrm{C} / \mathrm{T}$ and IFN- $\gamma \mathrm{R} 1-611 \mathrm{~A} / \mathrm{G}$ were not associated with HPV susceptibility, and the serum levels of IFN- $\gamma$ were not statistically different between different genotypes.

\section{Conclusion}

The polymorphism of IFN- $\gamma+874$ T/A was associated with HPV susceptibility in rural women from Luohe, Henan,
China, and $+874 \mathrm{~A}$ carriers had an increased risk of HPV infection. The possible mechanism was that $+874 \mathrm{~A}$ carriers had a low production of IFN- $\gamma$.

\section{Acknowledgments}

This work was supported by the Project for Outstanding Young Scholars of Luohe, Key Project of Colleges and Universities in Henan Province (contract number: 17B320011), Project of Luohe Medical College (contract number: 2016-SLMC-11) and Huimin Project of Science and Technology in Henan Province (contract number: 142207310008).

\section{Disclosure}

The authors report no conflicts of interest in this work.

\section{References}

1. Bailey HH, Chuang LT, Dupont NC, et al. American society of clinical oncology statement: human papillomavirus vaccination for cancer prevention. J Clin Oncol. 2016;34(15):1803-1812.

2. Lavigne AW, Triedman SA, Randall TC, Trimble EL, Viswanathan AN. Cervical cancer in low and middle income countries: Addressing barriers to radiotherapy delivery. Gynecol Oncol Rep. 2017;22:16-20.

3. Ferlay J, Soerjomataram I, Dikshit R, et al. Cancer incidence and mortality worldwide: sources, methods and major patterns in GLOBOCAN 2012. Int J Cancer. 2015;136(5):E359-E386.

4. Kim K, Zang R, Choi SC, Ryu SY, Kim JW. Current status of gynecological cancer in China. J Gynecol Oncol. 2009;20(2):72-76.

5. Wu C, Zhu X, Kang Y, et al. Epidemiology of Humanpapilloma virus infection among women in Fujian, China. BMC Public Health. 2017; 18(1):95.

6. Dickson EL, Vogel RI, Luo X, Downs LS. Recent trends in type-specific HPV infection rates in the United States. Epidemiol Infect. 2015;143(5): 1042-1047.

7. Doorbar J, Quint W, Banks L, et al. The biology and life-cycle of human papillomaviruses. Vaccine. 2012;30 Suppl 5:F55-F70.

8. Ortiz AP, Romaguera J, Pérez CM, et al. Prevalence, genotyping, and correlates of anogenital HPV infection in a population-based sample of women in Puerto Rico. Papillomavirus Res. 2016;2:89-96.

9. Einstein MH, Schiller JT, Viscidi RP, et al. Clinician's guide to human papillomavirus immunology: knowns and unknowns. Lancet Infect Dis. 2009;9(6):347-356.

10. Goodman MT, Shvetsov YB, Mcduffie K, et al. Prevalence, acquisition, and clearance of cervical human papillomavirus infection among women with normal cytology: Hawaii Human Papillomavirus Cohort Study. Cancer Res. 2008;68(21):8813-8824.

11. Schiffman M, Castle PE, Jeronimo J, Rodriguez AC, Wacholder S. Human papillomavirus and cervical cancer. Lancet. 2007;370(9590): 890-907.

12. Grulich AE, van Leeuwen MT, Falster MO, Vajdic CM. Incidence of cancers in people with HIV/AIDS compared with immunosuppressed transplant recipients: a meta-analysis. Lancet. 2007;370(9581):59-67.

13. Palefsky J. Human papillomavirus infection among HIV-infected individuals. Implications for development of malignant tumors. Hematol Oncol Clin North Am. 1991;5(2):357-370.

14. Kobayashi A, Weinberg V, Darragh T, Smith-Mccune K. Evolving immunosuppressive microenvironment during human cervical carcinogenesis. Mucosal Immunol. 2008;1(5):412-420.

15. Song SH, Lee JK, Lee NW, et al. Interferon-gamma (IFN-gamma): a possible prognostic marker for clearance of high-risk human papillomavirus (HPV). Gynecol Oncol. 2008;108(3):543-548. 
16. Yang W, Song Y, Lu YL, Sun JZ, Wang HW, Yl L. Increased expression of programmed death (PD)-1 and its ligand PD-L1 correlates with impaired cell-mediated immunity in high-risk human papillomavirus-related cervical intraepithelial neoplasia. Immunology. 2013; 139(4):513-522.

17. Critchley-Thorne RJ, Simons DL, Yan N, et al. Impaired interferon signaling is a common immune defect in human cancer. Proc Natl Acad Sci U S A. 2009;106(22):9010-9015.

18. Day PM, Thompson CD, Lowy DR, Schiller JT. Interferon Gamma Prevents Infectious Entry of Human Papillomavirus 16 via an L2Dependent Mechanism. J Virol. 2017;91(10):e00168-17.

19. Naderi M, Hashemi M, Rezaei M, Safdari A. Association of Genetic Polymorphisms of IFNGR1 with the Risk of Pulmonary Tuberculosis in Zahedan, Southeast Iran. Tuberc Res Treat. 2015;2015:292505-5.

20. He J, Wang J, Lei D, Ding S. Analysis of functional SNP in ifng/ ifngr1 in Chinese Han population with tuberculosis. Scand J Immunol. 2010;71(6):452-458.

21. Pravica V, Perrey C, Stevens A, Lee JH, Hutchinson IV. A single nucleotide polymorphism in the first intron of the human IFN-gamma gene: absolute correlation with a polymorphic CA microsatellite marker of high IFN-gamma production. Hum Immunol. 2000;61(9): 863-866.

22. Bach EA, Aguet M, Schreiber RD. The IFN gamma receptor: a paradigm for cytokine receptor signaling. Annu Rev Immunol. 1997;15:563-591.

23. Hashemi M, Moazeni-Roodi AK, Fazaeli A, et al. Lack of association between paraoxonase-1 Q192R polymorphism and rheumatoid arthritis in southeast Iran. Genet Mol Res. 2010;9(1):333-339.

24. Solé X, Guinó E, Valls J, Iniesta R, Moreno V. SNPStats: a web tool for the analysis of association studies. Bioinformatics. 2006;22(15): 1928-1929.

25. Hardikar S, Johnson LG, Malkki M, et al. A population-based casecontrol study of genetic variation in cytokine genes associated with risk of cervical and vulvar cancers. Gynecol Oncol. 2015;139(1):90-96.

26. Turner DM, Williams DM, Sankaran D, et al. An investigation of polymorphism in the interleukin-10 gene promoter. Eur J Immunogenet. 1997;24(1):1-8

27. Kroeger KM, Carville KS, Abraham LJ. The -308 tumor necrosis factoralpha promoter polymorphism effects transcription. Mol Immunol. 1997; 34(5):391-399.

28. Fishman D, Faulds G, Jeffery R, et al. The effect of novel polymorphisms in the interleukin-6 (IL-6) gene on IL-6 transcription and plasma IL-6 levels, and an association with systemic-onset juvenile chronic arthritis. J Clin Invest. 1998;102(7):1369-1376.

29. Pravica V, Asderakis A, Perrey C, et al. In vitro production of IFNgamma correlates with CA repeat polymorphism in the human IFNgamma gene. Eur J Immunogenet. 1999;26(1):1-3.
30. Marangon AV, Guelsin GA, Visentainer JE, et al. The association of the immune response genes to human papillomavirus-related cervical disease in a Brazilian population. Biomed Res Int. 2013;2013:146079-11.

31. Zur Hausen H. Papillomaviruses and cancer: from basic studies to clinical application. Nat Rev Cancer. 2002;2(5):342-350.

32. Ho GY, Bierman R, Beardsley L, Chang CJ, Burk RD. Natural history of cervicovaginal papillomavirus infection in young women. $N$ Engl $J$ Med. 1998;338(7):423-428.

33. Chen X, Jiang J, Shen H, Hu Z. Genetic susceptibility of cervical cancer. J Biomed Res. 2011;25(3):155-164.

34. Daud II, Scott ME, Ma Y, et al. Association between toll-like receptor expression and human papillomavirus type 16 persistence. Int $J$ Cancer. 2011;128(4):879-886.

35. Haralambieva IH, Ovsyannikova IG, Umlauf BJ, et al. Genetic polymorphisms in host antiviral genes: associations with humoral and cellular immunity to measles vaccine. Vaccine. 2011;29(48):8988-8997.

36. Hibma MH. The immune response to papillomavirus during infection persistence and regression. Open Virol J. 2012;6:241-248.

37. Sasagawa T, Takagi H, Makinoda S. Immune responses against human papillomavirus (HPV) infection and evasion of host defense in cervical cancer. J Infect Chemother. 2012;18(6):807-815.

38. Feng Q, Wei H, Morihara J, et al. Th2 type inflammation promotes the gradual progression of HPV-infected cervical cells to cervical carcinoma. Gynecol Oncol. 2012;127(2):412-419.

39. Billiau A, Heremans H, Vermeire K, Matthys P. Immunomodulatory properties of interferon-gamma. An update. Ann N Y Acad Sci. 1998;856: 22-32.

40. Telesheva LF, Dolgushina VF, Abramovskikh OS, et al. Cytokine status of cervical mucus in women with transitory and persistent course of papillomavirus infection. Zh Mikrobiol Epidemiol Immunobiol. 2012;4(4):118-121.

41. Sun Y, Lu Y, Xie L, et al. Interferon gamma polymorphisms and hepatitis B virus-related liver cirrhosis risk in a Chinese population. Cancer Cell Int. 2015;15:35.

42. Schena FP, Cerullo G, Torres DD, et al. Role of interferon-gamma gene polymorphisms in susceptibility to IgA nephropathy: a family-based association study. Eur J Hum Genet. 2006;14(4):488-496.

43. Mehta AM, Mooij M, Branković I, et al. Cervical Carcinogenesis and Immune Response Gene Polymorphisms: A Review.JImmunol Res. 2017; 2017:8913860-12.

44. Holla LI, Hrdlickova B, Linhartova P, Fassmann A. Interferon- $\gamma+874 \mathrm{~A} / \mathrm{T}$ polymorphism in relation to generalized chronic periodontitis and the presence of periodontopathic bacteria. Arch Oral Biol. 2011;56(2):153-158.

45. Sun Y, Lu Y, Li T, et al. Interferon Gamma +874T/A Polymorphism Increases the Risk of Hepatitis Virus-Related Diseases: Evidence from a Meta-Analysis. PLoS One. 2015;10(5):e0121168.
OncoTargets and Therapy

\section{Publish your work in this journal}

OncoTargets and Therapy is an international, peer-reviewed, open access journal focusing on the pathological basis of all cancers, potential targets for therapy and treatment protocols employed to improve the management of cancer patients. The journal also focuses on the impact of management programs and new therapeutic agents and protocols on

\section{Dovepress}

patient perspectives such as quality of life, adherence and satisfaction. The manuscript management system is completely online and includes a very quick and fair peer-review system, which is all easy to use. Visit http://www.dovepress.com/testimonials.php to read real quotes from published authors. 